\title{
WEED MANAGEMENT STUDIES IN KHARIF GROUNDNUT THROUGH PROMISING HERBICIDES ALONE OR IN COMBINATION WITH CULTURE PRACTICES.
}

\author{
S. N. Bhongade and K. D. Khattar \\ Department of Agronomy, College of Agriculture, Nagpur, Maharashtra, India \\ * For correspondence. (email: dmgaidhane1969@gmail.com)
}

\begin{abstract}
:
Groundnut is being an important cash crop of Maharashtra and particularly in Vidarbha region, needs greater attention for adopting suitable measures for weed control, so as to obtain optimum benefit of the various cultural practices recommended for the cultivation of crop. The present investigation was carried out in a randomized block design with 15 treatments, replicated 4 times at the Agriculture College Farm, Nagpur, on Field No. 3, Jali block. The crop of groundnut variety SB XI was grown on silty-clay type of soil which has low nitrogen and medium available phosphorus and potash content. The treatments comprised of three herbicides, viz., Basalin, Lasso and Fusilade, used either alone at their higher or lower doses or in combination of pre- and/or post-emergence spray of herbicides or cultural method. Regular periodical observations were taken in respect of emergence plant, plant population count, plant height, etc. No adverse or toxic effect of any of the herbicides applied at higher or lower dose was noticed on the seed emergence, plant count, crop growth, development and finally, the yield of pods in different treatments. From the gist of experimental findings, it was concluded that, none of the herbicides produced any adverse or toxic effect on the emergence and plant stand as well as development of groundnut crop. Pod yield per hectare as well as straw yields was significantly increased under the treatment of Basalin, Lasso and Fusilade. The use of herbicides should be invariably adapted, wherever; the labour is either not easily available or costly. However, these findings need to be repeated for another one or two more seasons, to get confirmatory results for the purpose of recommendations to the cultivators.
\end{abstract}

Key words: - Groundnut, kharif crop, weed management, herbicides, Basalin, Lasso, Fusilade.

\section{INTRODUCTION:}

INDIA is one of the leading countries in respect of groundnut cultivation, having an area of 6.9 million hectares with a total production of 5.0 million tonnes of pods. In Maharashtra's Vidarbha region, groundnut is mainly grown as an important commercial and oil seed crop, occupying an area of 2,43,000 hectares and $2,64,000$ tonnes pods production as against $61,71,000$ hectares area and 41,94,000 tonnes of pods production in Maharashtra. Groundnut thus, being a important cash crop of Maharashtra and particularly in Vidarbha region, needs greater attention for adopting suitable measures for weed control, so as to obtain optimum benefit of the various cultural practices recommended for the cultivation of crop. The crop is quickly dominated by the weeds during early growth stage on account of slow emergence of crop plants. Weeds also prevent efficient utilization of nutrients, moisture and sunlight by the crop. The crop development is checked, which results in erect development, leading to poor entrans of gynophores into the soil and ultimately hampering the pod formation.

Weeds not only lower the pod yield of groundnut crop but also impair the quality on account of reduction in size of pods. Weeds also increase the cost of tillage and other crop 
operations, such as harvesting, drying and cleaning. Weeds also increase the infestation of insect pests and diseases in the crop. There is a keen weeds competition in the early stage of growth, on account of favourable weather conditions after sowing upto 30-35 days period. Weeds therefore, must be checked at proper time. Losses to groundnut crop in the form of sizeable reduction in pod yield from 28 to $70 \%$ have been reported by various research workers, viz., Misari et al., (1980), Krishnamurthy et al., (1983), Murthy et al., (1994), Devi Dayal et al.,(1994), Patra and Nayak (2001), Jat et al., (2011), etc.

The traditional method of cultural weed control is adopted by the farmers in most of the field crops including groundnut because the labour and implements are easily available in the rural areas. Moreover, it is cheaper method and easy to adopt. Chemical weed control through herbicides needs proper skill and could be applied by giving suitable orientation to the cultivators. Herbicides application can be considered as an alternative to the culture method under situations, where the soil is inaccessible to the working of implements. In the event of delay inter-cultural operations, mechanical injury to the developing gynophores could be avoided by spray of appropriate herbicides at its/there suitable concentrations. Use of herbicides in the groundnut crop is of recent origin and it is the outcome of development of selective herbicides like Amiben, Basalin, Basagran, Lasso, Fusilade, Illoxan, etc. and thus, it has enhanced the scope of weed control in groundnut. However, efficiency of herbicides is bound to vary depending upon the active ingredients, soil type and climatic conditions. Moreover, any herbicide that is recommended for use by the cultivators, should be conveniently available in the market like any other pesticides.

Before the technology is recommended for transfer to the cultivators, it is necessary to test their efficiency with regards the phytotoxic action on weeds and crop plants, as well as residual effect on the succeeding crops. It is also necessary to study the different species of weeds associated with the crop for planning efficient weed control methods. Out of various recently introduced herbicides, Basalin, Lasso (Alachlor) and Fusilade are reported to be selective, systemic weed killers and have been tried to control most of broad leaved weeds and grassy weeds efficiency.

By keeping these views in points, the present research was planned to study the efficiency of promising herbicides alone or in combination with cultural practices in kharif groundnut (Latin: Arachis hypogaea) crop variety SB XI with the following objectives:

1. To study the relative efficiency of chemical and mechanical weed control or combination of these in kharif groundnut crop for effective weed control.

2. To study the relative efficiency of different herbicides used for weed control in groundnut crop.

3. To study the effect of different herbicides on annual monocot, dicot as well as perennial weeds in the groundnut.

4. To study the uptake of nitrogen by weeds and crop,

5. To find out suitable combination of herbicides for effective and economic weed control in groundnut.

\section{MATERIAL \& METHODS:}

The details of materials used and methods adopted in the present investigations on weed management in groundnut crop are narrated here under appropriate heads as follows:

\section{Experimental site:}

The present investigation was carried out at the Agriculture College Farm, Nagpur on Field No. 3, Jail Block, besides the proposed College library building site during kharif season 1984 on medium black soil. 


\section{A. Soil:}

The soil samples of surface layer $(0$ to $20 \mathrm{~cm})$ were collected from about 20 randomly selected spots before lay-out of the experiment. A composite soil sample from these samples thus collected, was prepared and analysed for the physico-chemical properties. Physical/mechanical components includes sand, silt and clay while in chemical components observed were total nitrogen, available phosphorus, available potassium, organic carbon and electrical conductivity.

B. Cropping history: Cropping history of the experimental plot in the last three years is presented in Table 1

The cropping history of the experimental plot revealed that groundnut was taken in kharif season and it was followed by either wheat or tur and gram during the rabbi season.

\section{Climate and weather conditions:}

Nagpur is situated in sub-tropical region at $21^{\circ}$ 10。 North latitude and 79० -19० East longitude. It is 321 meters above sea level. The average rainfall is $1145 \mathrm{~cm}$. received during June to October. Nagpur has cold winter and hot summer. Humidity varies from 20\% during summer and 90\% during rainy season. Wind velocity ranges from 2.41 to $12.07 \mathrm{~km} / \mathrm{hr}$. Bright sunshine hours vary from 3 to 8 hours per day.

\section{Experimental details:}

2.1. Field operations: Details of cultural operation carried out on the field during cropping season are given in Table 2 .

\subsection{Experimental design: Experimental design} is given in Table 3.

\subsection{Experimental treatments:}

Treatment details along with the symbol used for each treatment are given in Table 4.
2.4. Details of observations: List of various biometric observations recorded during the course of present investigations are given in Table 5.

Weed control:

1. Basalin: Basalin is a trade name of Fluchloralin (BASF India Limited). Chemically it is (N-propyl-N (2'chloroethyl 1)-2-6-dinitro-ntrifluro-methyl aniline). It is sold in the market as emulsifiable concentrate and formulated as 48 Ec. It is a selective herbicide and does not harm leguminous crops. Basalin penetrates germinating seedlings of weed (both monocot and dicot), mainly through hypocotyls and roots and kills them before or shortly after emergence. Basalin hardly acts through leaves and has therefore very little effect on established weeds. It is recommended as a presowing or pre-emergence herbicides. Basalin control most of the annual grasses such as Echinocloa eleusine, Digitaria sanguinalis, Eragrostis minor, Phalaris minor, Poa annua, Sataria glauca as well as broad leaved weeds such as Digera arvensis, Amaranthus Spp., Chenopodium album, Euphorbia Spp.

2. Lasso: Lasso is a trade name of Alachlor (Monsanto Agril. Product Company). Chemically, it is 2-chloro-2'-6'diethyl-N(Methoxy methyl acetanilide). It is sold in the market as an emulsifiable concentrate and formulated as $50 \mathrm{Ec}$. It is a selective herbicide and it is to be sprayed post-sowing preemergence on freshly prepared seed bed. It does not have carry over effect. After about 12 weeks, Lasso breaks down and disappears. Lasso weed killing action needs only minimum moisture on dry soil surface. Slight mixing of upper $2.5 \mathrm{~cm}$. layer of soil is advisable. Lasso killing action is through roots and growing points. Lasso control many annual grasses like Digitaris sanguinalis, Elusine indica and broad leaved weeds such as 
Chenopodium album, Amaranthus Spp., Mollugo verticillata, etc.

3. Fusilade: Fusilade is a trade name of Fluazifop butyl, a highly selective herbicide for control of grasses in broad leaved crops. It is a systemic herbicide and translocates in both xylom and phloem when it is given as postemergence application. It translocates into the roots, stolens and rhizomes of perennial grasses and results in death of grassy weeds. Rains followed just one hour after spraying virtually nullify the herbicidal activity. Active growth ceases two days after spraying and complete mortality of weed takes 3 to 4 weeks after treatment. It is sold in the market as a emulsifiable concentrate as 12.5 Ec. formulation.

\subsection{Herbicial application:}

A spray solution of each of the herbicides, viz., Basalin, Lasso and Fusilade of the desired concentration was prepared as per treatment in 500 litres of water per hectare. The spray solution of each of the herbicides was thoroughly stirred and pre- and postemergence application was carried out with the help of previously cleaned and washed spray pump at the appropriate time for the treatment. Uniform spray was carried out by using wind screens to prevent drifting.

2.7. Inter-culture: Hoeing and weeding were done as per treatment.

2.8. Crop variety: The variety $\mathrm{SB}$ XI of groundnut used in present investigation has a good yielding potential. It matures in about 110 days and is widely grown by cultivators of Nagpur region.

2.9. Fertilizer application: The basal dose of fertilizer@ 25 kg N/ha and $\mathrm{P}_{2} \mathrm{O}_{5}$ (Phosphorus) (a) $50 \mathrm{~kg} / \mathrm{ha}$ in the form of Urea and Single Superphosphate, respectively, were applied to the soil in the experimental block. The fertilizer was spread evenly and mixed uniformly in each of the plot before sowing of the crop.

2.10. Details of Observations: The details of the observations recorded in the present investigations are given in Table 4 . The methods followed for recording each of the observations are also described separately.

A. Crop growth studies: The periodical observations on plant height, number of functional leaves, number of branches, number of nodules, number of pods and dry matter per plant were periodically recorded at 14 days interval, on five randomly selected plants in each of the treatment plot after labelling them properly.

A.1. Emergence count: The emergence count was recorded twice on $10^{\text {th }}$ and $21^{\text {st }}$ day of sowing. Final plant population count was taken in net plot area, at harvest.

A.2. Plant height, number of functional leaves and number of branches: The height of five selected plants was measured from ground level upto the base of emerging leaf at every 14 days interval. So also the number of fully opened leaves and number of branches per plant were counted on five sample plants, respectively.

A.3. Number of nodules: Number of nodules per plant from the plants uprooted for dry matter was recorded periodically.

A.4. Number of gynophores and pods: Number of gynophores and pods per plant of each of the randomly selected sample plant uprooted for dry matter, were counted and recorded at 49, 63,77 , and 91 days after sowing and at harvest.

A.5. Dry matter produced per plant: Dry matter produced by each plant was recorded in grams periodically in the case of randomly uprooted sample plants. The entire plant was taken out without causing any damage to roots and number of nodules, gynophores, pods per plant was counted. Thereafter, the above ground 
parts of the plants were used for dry matter studies. The sample plants were first air-dried for 3-4 days and again finally dried in the oven at $60^{\circ} \mathrm{C}$ to attain constant weight.

\section{B. Yield studies:}

B.1. Pod weight per plant: The pods were stripped off from the uprooted sample plants and their weight per plant recorded after complete drying in the sun.

B.2. Pod yield per plot: Pod weights per net plot were recorded in the same manner, as under B.1.

B.3. Straw yield per plot: The plants were air dried after harvest and their weight per plot was recorded after complete drying in hot sun.

B.4. Pod: Straw ratio: Pod: Straw ratio was calculated for each of the treatments on the basis of pod and straw yield from each plot.

\section{Weed studies:}

C.1. Weed count: Area measuring one square meter was selected at random in each experimental plot within the net area. It was marked with the pegs and weed count for broad leaves, grasses and perennial weeds were recorded at every 14 days interval from 21 days after sowing.

C.2. Dry weight of weeds: After removal of groundnut crop, the net plot area of each treatment was hand weeded, after recording the weed count of broad leaf species and grasses, annual and perennial. The bundles of the weed were tied, labelled treatment wise and dried in the sun for sufficient period. Finally, the dry weight of weeds in the net plot was recorded.

\section{Chemical studies:}

D.1. Nitrogen uptake by weeds and crop: A composite sample for plants and weeds was taken for nitrogen uptake studies separately from each of the net treatment plots. The analysis was carried out by modified Kjeldahls method and the uptake of nitrogen was calculated on the basis of percentage.

2.11. Economics of weed control: Economics of chemical and cultural methods of weed control over unweeded control was worked out from the yield data (Pod + Straw) in terms of monetary values by taking into consideration the prevailing market rates of herbicides, materials, pods and labour cost.

2.12. Harvest index: The harvest index was worked out by using the following formula:

Harvest index (H.I.) $=\frac{\text { Pod yield }}{\text { Straw yield }+ \text { Pod }} \times 100$

2.13. Weed index: The weed index was calculated by the formula proposed by Gill and Vijay Kumar (1966) as follows:

$$
\text { Weed index (W.I.) }=\frac{\mathrm{X}-\mathrm{Y}}{\mathrm{Y}} \times 100
$$

Where as,

$$
\begin{aligned}
& X=\text { Yield from weed free plot, } \\
& Y=\text { Yield from treatment plot for }
\end{aligned}
$$
which W.I. is to be calculated.

\subsection{Herbicidal efficiency index: The herbicidal} efficiency index (H.E.I.) was calculated by the formula suggested by Krishnamurthy et al., (1975). H.E.I. was based on yield of crop and dry matter of weeds. It is as follows:

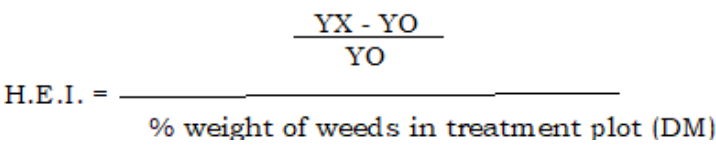

Whereas,

$\mathrm{YX}=$ Yield crop in herbicidal treatment plot.

YO $=$ Yield under absolute control treatment plot.

$\%$ weight of we $\epsilon \frac{\text { Dry matter weights of weeds in treated plot }}{\text { Dry matter weights of weeds in untreated plot }} \times 100$ 
The H.E.I. should be always 'O' in absolute control, i.e., weedy check.

3. Statistical analysis: The statistical analysis of data was carried out by Fisher's method of 'Analysis of Variance (ANOVA)'. The 'Null Hypothesis' was tested by using ' $\mathrm{F}$ ' test of significance in order to ascertain whether the observed treatment effects were real or otherwise, through chance effects. Wherever the treatment effects were found to be significant, the appropriate Standard Error (S.E.) and Critical Difference (C.D.) were worked out at $5 \%$ level of significance.

\section{RESULTS \& DISCUSSION:}

The results of the present investigation are explained under following five heads:

I. Growth studies,

II. Yield studies,

III. Weed studies,

IV. Chemical studies, and

V. Economics of weed control.

\section{Growth studies:}

1. Emergence and plant population count: Data regarding emergence and plant population count showed that there is no significant differences in emergence count and plant population count were observed in different treatments at 10 and 21 days after sowing. The final plant population count at harvest in different treatment plots did not show any significant differences.

2. Plant height: A perusal of observations on plant height shows that, the differences were significant and more or less consistent from 35 DAS upto harvest. Plants were taller under cultural weed control treatment plots in comparison with herbicidal weed control treatments.

3. Number of leaves: The data revealed that the cultural weed control treatment (TN14) recorded maximum number of leaves per plant and was significantly superior to rest of the weed control treatments.

4. Number of branches: At harvest, the cultural weed control treatment (TN14) recorded maximum number of branches followed by TBF8, TB2, TBF7, which in turn were at par with each other. Weedy check (TC15) recorded lowest number of branches over all other weed control treatments and was significantly inferior.

5. Number of nodules: No adverse effect of different weed control treatments were observed in respect of nodules count.

6. Number of gynophores: The data revealed that no significant influence on development on gynophores per plant was observed due to different weed control treatments.

7. Number of pods per plant: The weedy check (TC15) produced the least number of pods per plant (8.80). It was at par with treatment Fusilade@0.50 1/ha (TF5) and statistically inferior to rest of weed control treatments.

8. Dry matter per plant: No significant differences were observed due to various weed control treatments in respect of dry matter production per plant.

\section{Yield studies:}

1. Pod weight per plant: There were no significant differences in pod weight per plant due to different weed control treatments.

2. Test weight: There were no significant differences in test weight due to various weed control treatments.

3. Pod yield: It is observed from the statistical analysis of pod yield data that differences due 
to various weed control treatments were significant at 5\% level.

4. Straw yield: The results of straw yield per plot in the various weed control treatments were found to be significant.

5. Pod:Straw ratio: The results showed that the pod:straw ratio in respect of TLF9 was 1:2.24 which appeared to be the highest, amongst all weed control treatments.

6. Harvest index: The data on the harvest index indicates that the highest value of 41.72 and 39.50 were found in treatment TBF8 and TBI13 respectively. The next in order or merit were TL4 and TBF7, which gave values of 39.20 and 36.58 , respectively.

\section{Weed studies:}

1. Weed flora: The experimental crop of groundnut was sown on $3^{\text {rd }}$ July, 1984, i.e., $27^{\text {th }}$ meteorological week on a weed free plot. The association of different weed species of weed flora with the crop was studied by observing them in unweeded control plot. It would be seen that prominent monocot annuals and perennial weeds were Eragrostis minor, Avena fatua, Dinebra Arabica and Cyperus rotandus species. Amongst the dicot weeds, dominance of Phyllanthus niruri, Amaranthus spp., Dicera arvensis, Parthenium histerophorus and Psoralea corylifolia were noticed. Most severe weed competition was observed upto 35 DAS and subsequently the weed population decreased but monocot weeds persisted till harvest. Dicot weed population decreased 63 days after sowing.

2. Effect of herbicides on weed population: The average weed count data recorded periodically in each treatment in one square meter area.

3. Effect on monocot weeds: Overall results indicate that combined application of Basalin pre-sowing plus Fusilade post-emergence application at their lower and higher doses
(TBF7 and TBF8) gave lower number of monocot weeds per square meter.

4. Effect on dicot weeds: The data revealed that differences due to weed control treatments were significant from 21 DAS to 91 DAS, At harvest, the treatment effects were non-significant, indicating that no weed control treatment effects were observed upto harvesting stage of crop.

5. Effect on perennial weeds: The perusual of data on perennial weed population indicate that the differences due to treatment were significant only 49 days after sowing.

6. Mortality percentage:

A. Monocot weed mortality: The treatments TBF7, TBF8, TLF10, TF6 and TN14 showed mortality of monocot weeds in comparison with other weed control treatments.

B. Dicot weeds mortality: The data on dicot weed mortality indicates that, cultural weed control treatment (TN14) showed the highest mortality from 78 to $100 \%$ at different intervals.

C. Perennial weed mortality: The data on perennial weed mortality indicates that, cultural weed control treatment (TN14) showed the maximum weed mortality which ranged from 83 to 100 at different levels.

7. Dry weight of weeds and index values:

A. Dry weight of weeds: The perusual of data on dry weight of weeds at harvest indicates that significantly lowest dry weight of $10.57 \mathrm{q} /$ ha (Quintal per hectare) was recorded under the cultural weed control treatment (TN14) and was at par with TB2 (21.22 q/ha), TBF7 (22.30 q/ha), TBF8 (17.90 q/ha) and TBI13 (23.21 $\mathrm{q} / \mathrm{ha}$ ). The highest dry weight was produced in unweeded check (TC15) (46.93 q/ha) and it was comparable with TF5 (34.03 q/ha). 
B. Weed index: The weed index values in different weed control treatments showed negative values.

C. Herbicidal efficiency index: The data on the Herbicidal efficiency index (H.E.I.) revealed that all the treatments gave positive values.

\section{Chemical studies:}

Nitrogen uptake by weeds and crop plants: The perusal of data on $\mathrm{N}$-uptake by weeds show that, highest $\mathrm{N}$-uptake by unweeded check (TC15) $(2240.79 \mathrm{~kg} / \mathrm{ha})$ and least N-uptake by weeds was noticed in cultural weed control treatments (TN14) (44.52 kg/ha), while considering the herbicidal weed control treatments, it could be seen that TBF8 (44.78 kg/ha), TBF7 (64.69 kg/ha),TB2 (61.45 kg/ha) and TB1 (73.87 kg/ha) N-uptake by weeds was observed.

As regards N-uptake by groundnut plants, the result indicate that highest $\mathrm{N}$-uptake of 165.37 $\mathrm{kg} / \mathrm{ha}$ was found in cultural weed control treatment (TN14).

$\mathrm{N}$-uptake by crop plants in herbicidal weed control treatments TBF8 (118.46 kg/ha), TB2 (153.32 kg/ha), TB1 (124.49 kg/ha), TBI13 $(107.14 \mathrm{~kg} / \mathrm{ha})$ was recorded. Lowest $\mathrm{N}$-uptake of $44.52 \mathrm{~kg} /$ ha was recorded in weedy check (TC15).

\section{Economics of Weed control:}

The data clearly indicate that the cultural weed control treatment (TN14) gave the maximum net return of Rs. 8504.40 closely followed by TBF 8 (Rs. 8002.10) and TB2 (Rs. 7823.20), the two herbicidal treatments, with a corresponding reduction of $5 \%$ and $8 \%$ respectively over the former.

The highest net profit of Rs. 13.60 rupee spent was obtained in case of treatment Basalin @ $0.751 /$ ha (TB1); the other weed control treatments TB2, TL3, TBI13 and TN14 closely followed, giving a net profit of Rs. 10.86, 10.00, 9.79 and 7.18 per rupee spent respectively.

So far as the labour cost is concerned it was found that $6.93 \%$ labour cost was required for cultural weed control treatment (TN14) which was the highest of all the weed control treatments followed by TBI13, TLI12, TFI11, giving the labour cost of Rs. 2.00, 2.24, 2.33, respectively.

\section{Conclusions}

The present investigation entitled 'Studies on weed management in kharif groundnut through promising herbicides alone or in combination with cultural practices' was carried out in a randomized block design with fifteen treatments, replicated 4 times, at the Agriculture College Farm, Nagpur on Field No. 3, Jali Block. The crop of groundnut variety SB XI was grown on silty-clay type of soil, which had low nitrogen and medium available phosphorus and potash content. The treatment comprised of three herbicides, viz., Basalin, Lasso and Fusilade, used either alone at their higher or lower doses or in combination of preand/or post-emergence spray of herbicides or the cultural method. The lower concentration of Basalin, Lasso and Fusilade were 0.75 1/ha, 1.501 /ha and 0.501 / ha (Commercial product) where as the corresponding higher doses were double of the respective lower doses of the herbicides. The sowing of the crop was done on $3^{\text {rd }}$ July, 1984 in the experimental area. The pre-sowing soil incorporation of Basalin was done four days before sowing, while Lasso was sprayed immediately after sowing and Fusilade was applied 21 days after sowing of groundnut crop. A comparison between the cultural method and chemical method of weed control was done and the effect of herbicides on the growth and yield of groundnut crop and weeds, as well as the economics of weed control were worked out. Effect of weather on crop growth 
and weed intensity was recorded during the cropping season. Regular periodical observations were taken in respect of emergence count, plant population count, plant height, number of leaves, branches, nodules and gynophores. The weight of dry matter and yield at harvest time were also recorded. Further the effect of herbicides on weed population, weeds mortality and dry matter production by weed in different treatments were also studied. Indices for yield and weeds were worked out, to assess the comparative efficiency of herbicides.

From the above gist of the experimental findings, following conclusions can be drawn:

1.None of the herbicides produced any adverse and toxic effects on the emergence and plant stand as well as development of groundnut crop.

2.The mean plant height, average number of functional leaves and branches per plant were markedly influenced by the cultural weed control treatment (TN14) as well as the herbicidal treatments (TBF8) and (TB2). i.e., Basalin in combination with Fusilade at their higher dose or Basalin alone at its corresponding higher doses. Pod yields per hectare as well as the straw yield were significantly increased under these treatments and the values were higher than the other weed control treatments.

3. Lowest value of N-uptake by weeds (24.09 $\mathrm{kg} / \mathrm{ha}$ ) was observed in case of TN14.

4. Maximum net return of Rs. 8504.40/ ha was obtained under the treatment TN14, i.e., Cultural weed control treatment, which established superiority over all the treatments.

5.The lowest total expenditure on weed control was Rs.188.75/ha in the case of treatment TB1, which recorded the highest net profit of Rs. 13.60 per rupee spent on weed control.
6.The treatment TB2 gave the lowest value of $0.64 \%$ labour cost for weed control on net return as compared to all the other treatments included in the investigation.

\section{SUGGESTIONS}

With regard to the present investigation, following suggestions can be adapt in future:

1. It is proposed to adopt the cultural weed control method, wherever the fields are accessible at the time of weeding and interculturing as it gives optimum pod and straw yield per hectare as well as highest net return per hectare.

2. Use of herbicide should be invariably adopted, wherever the labour is either not easily available or costly.

3. Under inaccessible condition of soil during first 35-50 days after sowing, use of herbicide will be beneficial for efficient weed management.

4. Higher dose of pre-sowing application of Basalin alone@1.501/ha for the control of dicot weeds and few annual monocots or Basalin @ $1.501 /$ ha plus post-emergence spray of Fusilade@ 1.00 1/ha could be effective for season long control of monocot, dicot as well as perennial weeds in the crop of groundnut.

5. However, the above findings need to be repeated for another one or two more seasons to get confirmatory results for the purpose of recommendations to the cultivators.

\section{ACKNOWLEDGEMENTS}

The researcher Shri. S. N. Bhongade is grateful to Shri. Suresh Kumar, Director of Agriculture, Maharashtra State, Pune and Dr. S.K. Dorge, Additional Director of Agriculture, Maharashtra State, Pune for given him an opportunity of research during his in-service period, otherwise, M.Sc. (Agronomy) by research would have been a remote possibility for him. The authors are also thankful to Dr. V.G. Kakade, 
Associate Dean, College of Agriculture, Nagpur for providing the support and research facilities during the course of this investigation. Authors also gives special thanks to Dr. D. M. Gaidhane, Associate Professor, Janata Mahavidyalaya, Chandrapur, Maharashtra for his help during the preparation of manuscript and its publication.

\section{REFERENCES:}

Bajwa, A.A., Mahajan, G. and Chauhan, B.S., Non conventional weed management strategies for modern agriculture, Weed Sci., 2015, 63, 723-747.

Bhondve, T.S., Pinjari, S.S. and Suryawanshi, J.S., Integrated weed management in kharif groundnut (Arachis hypogaea L.), Int. J. Agri.Sci., 2009, 5(1), 158-160.

Chauhan, B., Grand challenges in weed management, Frontiers in Agronomy,2019, 1-3.

Chauhan, B.S., Weed ecology and weed management strategies for dry seeded rice in Asia. Weed Technol., 2012, 26, 1-13.

Chauhan, B.S. and Gill, G.S., Ecologically based weed management strategies, In: Recent advances in weed management, (Ed.: B.S. Chauhan and G. Mahajan, Springer Science + Business Media), 2014, 1-11.

Dayal, Devi, Naik, P.R., Dongre, B.N. and Reddy, P.S., Effect of row pattern and weed control method on yield and economics of rainfed groundnut, Indian J. Agric. Sci., 1994, 446-449.

Dubey, M. and Gangwar, S., Effect of chemical weed control of imazethapyr (Pursuit) in groundnut var. 'TG-24' Plant Archives, 2012, 12(2), 675-677.

Eslami, S.V., Weed management in conservation agriculture systems, In: Recent Advances in weed management (Ed.: Chauhan, B.S. and Mahajan, G.), Springer, New York, 2014, 87-124.

Gharde, Y. Singh, P.K., Dubey, R.P. and Gupta, P.K., Assessment of yield and economic losses in agriculture due to weeds in India, Crop Prot, 2018, 107, 12-18.

Ghosh D.C. and Mukhopadhyay, S.K., Weed and weed control in Sesame, Pesticide, 1980, 14(11), pp-24.

Heap, I., International survey of herbicide resistant weeds, Available online at www.weedscience.org (Accessed on August 10, 2019).

Jat, R.S., Meena, H.N., Singh, A.L., Surya, J.N., and Misra, J.B., Weed management in groundnut (Arachis hypogaea) in India - A review, Agri. Reviews, 2011, 32(3), 155-171.

Jain, V.K., Chauhan, Y.S., Bhargava, M.K. and Sharma, A.K., Chemical weed control in Soyabean (Glycine max), Indian J. Agron.,2000, 45(1), 153157. 
Kalhapure, A.K., Shetey, B.T., and Bodake, P.S., Integration of chemical and cultural methods for weed management in groundnut, Indian $J$. of Weed Sci., 2013, 45(2), 116-119.

Khattar, K.D., Wange, S.S. and Pawar, W.S., Studies on weeds associated with kharif groundnut and their susceptibility to different herbicides, In: Abst. of papers, Annual Conference of Indian Soc. of Weed Sci., 1983, pp-51.

Krishnamurthy, K., Raju, B., Reddy, V.G. and Kenchaiah, Critical stages of weed competition in Soyabean,Groundnut and Maize, In: Proc. of the Sixth Asian Pacific Weed Sci. Soc. Conference, Bangalore, India, 1983, Weed Abst., 32(12), pp369.

Lamichhane, J.R., Devos, Y., Beckie, H.J., Owen, M.D.K., Tillie, P., Messean, A., and Kudsk, P., Integrated weed management systems with herbicide-tolerant crops in European Union: Lessons learnt from home and abroad, Crit. Rev. Biotechnol., 2017, 37, 459-475.

Misari, S.M., Harkness, C. and Fowler, A.M., Groundnut production, utilization, research problems and further research in Nigeria. In: Proc. of Inter-national workshop on groundnut, Icrisat Centre, Patancheru, India, 13-17 Oct., 1980, 264-273.
Mukhopadhyay, S.K. and Ghosh, D.C., Weed and their control in seed crops, Pesticides, 1981, 15(12), 81-82.

Murthy, B.T.S. and Misra, A., Effect of different weed control practices on pod yield and nutrient uptake of rainfed groundnut under varying levels of fertilizer use, Indian J. weed Sci., 1979, 11(1-2), 81-82.

Murthy, B.G., Agasiami, C.A., Babalad, H.B. and Pratibha, N.C., Studies on integrated weed control in kharif groundnut, Farming System, 1994, 10, 66-69.

Patra, A.K., and Nayak, B.C., Integrated weed management in rainy season groundnut (Arachis hypogaea), Indian J. Agri. Sci., 2001, 71, 378380.

Priya, R.S., Chinnusamy, C., Manickasundaram, P., and Babu, C., A review on weed management in groundnut (Arachis hypogaea), Int. J. of Agric. Sci. and Res. (IJASR), 2013, 3(1), 163-172.

Rao., S.S., Madhavi, M. and Reddy, C.R., Integrated approach for weed control in Rabi groundnut (Arachis hypogaea), J. of Research ANGRAU, 2011, 39(1), 60-63.

Reddy, K.R., Rajan, M.S.S. and Reddy, G.H.S., Sequential application of herbicides in

groundnut, Agri. Sci. Digest, 1982, 2(1), 13. 
Scavo, A., and Mauromicale, G., Integrated weed management in herbaceous field crops, Agronomy, 2020, 10 (466), 1-26.

Scavo, A., Restuccia, A., Mauromicale, G., Allelopathy: General principles and basic aspects for agro-ecosystem control, In: Sustainable Agriculture Reviews, (Ed.: Gaba, S., Smith, B., and Lichtfouse, F.), Springer: Cham., Switzerland, 2018, 28, 47-101.

Sushiladevi, L. and Perur, N.G., Alachlor influences the activity of some enzyme systems in groundnut seedlings, Indian J. Weed Sci., 1983, 14(1), 28-30.

Yadav, S.K., Singh, S.P. and Bhan, V.M., Performance of herbicides for weed control in groundnut, Indian J. Weed Sci., 1983, 15(1), 58-61.

Walia, U.S., Singh, S. and Singh, B., Integrated approach for the control of hardy weeds in groundnut (Arachis hypogaea), Indian J. of Weed Sci., 2007, 39(1\&2), 112-115.

Table 1: Cropping history of experimental plot for the previous three years.

\begin{tabular}{|l|l|l|}
\hline \multirow{2}{*}{ Year } & \multicolumn{2}{|c|}{ Season-wise cropping } \\
\cline { 2 - 3 } & \multicolumn{1}{|c|}{ Kharif crop } & \multicolumn{1}{c|}{ Rabbi crop } \\
\hline $1981-$ & Groundnut SB & Wheat N-59 \\
82 & XI & $\begin{array}{l}\text { Tur and Gram. Double cropping } \\
\text { experiment. }\end{array}$ \\
\hline $1982-$ & Groundnut JL \\
83 & 24 & $\begin{array}{l}\text { Wheat, Mustard inter-cropping } \\
\text { experiment. }\end{array}$ \\
\hline $1983-$ & Groundnut SB \\
84 & XI & \multicolumn{2}{|l}{} \\
\hline
\end{tabular}

Table 2: Details of field operations.

\begin{tabular}{|c|c|c|c|c|}
\hline $\begin{array}{l}\text { Sr. } \\
\text { No. }\end{array}$ & Operations & $\begin{array}{c}\text { Frequen } \\
\text { cy }\end{array}$ & $\begin{array}{c}\text { Implements } \\
\text { used }\end{array}$ & $\begin{array}{c}\text { Dates of } \\
\text { operations }\end{array}$ \\
\hline A. & \multicolumn{4}{|c|}{ Preparatory tillage: } \\
\hline 1. & Ploughing & 1 & M.B. used & $20 / 05 / 1984$ \\
\hline 2. & Harrowing & 2 & Blade harrow & $\begin{array}{l}12 / 06 / 1984 \\
20 / 06 / 1984\end{array}$ \\
\hline 3. & Stubble picking & 1 & By hand & $22 / 06 / 1984$ \\
\hline 4. & Levelling & 1 & Plunk & $22 / 06 / 1984$ \\
\hline 5. & Row marking & 1 & Marker & $22 / 06 / 1984$ \\
\hline B. & \multicolumn{4}{|c|}{ Sowing: } \\
\hline 1. & Dibbling of seed & 1 & By hand & $03 / 07 / 1984$ \\
\hline 2. & Gap filling & 1 & By hand & $13 / 07 / 1984$ \\
\hline C. & \multicolumn{4}{|c|}{ Weed control: } \\
\hline 1. & $\begin{array}{l}\text { Pre-sowing application of } \\
\text { Basalin herbicide }\end{array}$ & 1 & $\begin{array}{l}\text { Low volume } 1 \mathrm{~L} \\
\text { capacity hand } \\
\text { pump }\end{array}$ & $28 / 06 / 1984$ \\
\hline 2. & $\begin{array}{l}\text { Pre-emergence spray of } \\
\text { Lasso }\end{array}$ & 1 & Special pump & $03 / 07 / 1984$ \\
\hline 3. & $\begin{array}{l}\text { Post-emergence spray of } \\
\text { Fusilade herbicide }\end{array}$ & 1 & Special pump & $25 / 07 / 1984$ \\
\hline
\end{tabular}




\begin{tabular}{|c|c|c|c|c|}
\hline 4. & $\begin{array}{c}\text { Hand weeding as per } \\
\text { treatment }\end{array}$ & 2 & By hand & $\begin{array}{c}05 / 08 / 1984, \\
20 / 08 / 1984\end{array}$ \\
\hline D. & Fertilizer application & 1 & By hand & $22 / 06 / 1984$ \\
\hline E. & $\begin{array}{c}\text { Pest and disease control } \\
\text { dusting }\end{array}$ & 1 & Duster & $24 / 08 / 1984$ \\
\hline F. & Harvesting & 1 & Manual labour & $31 / 10 / 1984$ \\
\hline
\end{tabular}

Table 3: Experimental design.

\begin{tabular}{|l|l|}
\hline $\begin{array}{l}\text { Experimental } \\
\text { design: }\end{array}$ & R.B.D. \\
\hline Replications: & Four \\
\hline Treatments: & Fifteen \\
\hline Gross plot size: & $\begin{array}{l}2.10 \times 6.00 \\
\mathrm{~m}^{2}\end{array}$ \\
\hline Net plot size: & $\begin{array}{l}1.50 \times 5.40 \\
\mathrm{~m}^{2}\end{array}$ \\
\hline $\begin{array}{l}\text { Spacings: } \\
\text { 1. Row to row } \\
\text { 2. Plant to plant }\end{array}$ & $30 \mathrm{~cm}$. \\
$15 \mathrm{~cm}$. \\
\hline
\end{tabular}

Table 4. Details of experimental treatments.

\begin{tabular}{|c|c|c|c|}
\hline $\begin{array}{l}\text { Sr. } \\
\text { No. }\end{array}$ & $\begin{array}{l}\text { Symbol } \\
\text { s }\end{array}$ & $\begin{array}{l}\text { Name and rate of application of } \\
\text { herbicides }\end{array}$ & Time of application \\
\hline 1 & TB 1 & Basalin lower dose@0.75 1/ha & Pre-sowing \\
\hline 2 & TB 2 & Basalin higher dose@1.501/ha & Pre-sowing \\
\hline 3 & TL 3 & Lasso lower dose@1.501/ha & $\begin{array}{l}\text { Post-sowing, Pre- } \\
\text { emergence }\end{array}$ \\
\hline 4 & TL 4 & Lasso higher dose@3.00 1/ha & $\begin{array}{l}\text { Post-sowing, Pre- } \\
\text { emergence }\end{array}$ \\
\hline 5 & TF 5 & Fusilade lower dose@0.50 1/ha & Post-emergence, 21 DAS \\
\hline 6 & TF 6 & Fusilade higher dose@1.00 1/ha & Post-emergence, 21 DAS \\
\hline 7 & TBF 7 & $\begin{array}{l}\text { Basalin lower dose +@0.75 1/ha } \\
\text { Fusilade lower dose + @ } 0.501 / \text { ha }\end{array}$ & $\begin{array}{l}\text { Pre-sowing }+ \\
\text { Post-emergence, } 21 \text { DAS }\end{array}$ \\
\hline 8 & TBF 8 & $\begin{array}{l}\text { Basalin higher dose +@1.50 1/ha } \\
\text { Fusilade higher dose @1.001/ha }\end{array}$ & $\begin{array}{l}\text { Pre-sowing + } \\
\text { Post-emergence,21 DAS }\end{array}$ \\
\hline 9 & TLF 9 & $\begin{array}{l}\text { Lasso lower dose }+@ 1.501 / \text { ha } \\
\text { Fusilade lower dose }+@ 0.501 / \text { ha }\end{array}$ & $\begin{array}{l}\text { Post-sowing, } \\
\text { Pre-emergence }+ \\
\text { Post-emergence, } 21 \text { DAS }\end{array}$ \\
\hline 10 & TLF 10 & $\begin{array}{l}\text { Lasso higher dose }+@ 3.001 / \text { ha } \\
\text { Fusilade higher dose @1.001/ha }\end{array}$ & $\begin{array}{l}\text { Post-sowing, } \\
\text { Pre-emergence + } \\
\text { Post-emergence, } 21 \text { DAS }\end{array}$ \\
\hline 11 & TFI 11 & $\begin{array}{l}\text { Fusilade lower dose +@ } 0.501 / \text { ha } \\
\text { One inter-culture }\end{array}$ & $\begin{array}{l}\text { Post-emergence, } 21 \text { DAS + } \\
25 \text { DAS }\end{array}$ \\
\hline 12 & TLI 12 & $\begin{array}{l}\text { Lasso lower dose + @1.501/ha } \\
\text { One inter-culture }\end{array}$ & $\begin{array}{l}\text { Post-sowing, } \\
\text { Pre-emergence + } 25 \text { DAS }\end{array}$ \\
\hline 13 & TBI 13 & $\begin{array}{l}\text { Basalin lower dose +@0.75 1/ha } \\
\text { One inter-culture }\end{array}$ & Pre-sowing + 25 DAS \\
\hline 14 & TN 14 & Recommended cultural practices & $\begin{array}{l}\text { One inter-culture } 25 \text { DAS } \\
+ \\
2 \text { weedings at } 35 \& 45 \\
\text { DAS }\end{array}$ \\
\hline 15 & TC 15 & Absolute control (Weedy check) & --- \\
\hline
\end{tabular}

TB, Treatment of Basalin; TL, Treatment of Lasso; TF, Treatment of Fusilade; DAS, Days after sowing; ha, Hectare; $@=$ At the rate of. 
Table 5. Details of Observations taken.

\begin{tabular}{|c|c|c|c|}
\hline $\begin{array}{l}\text { Sr. } \\
\text { No. }\end{array}$ & Particulars & Frequency & Days from sowing \\
\hline $\mathbf{A}$ & \multicolumn{3}{|l|}{ I. Crop Studies: } \\
\hline 1. & Emergence count & 2 & 10 and 21 days \\
\hline 2. & Plant population count & 1 & At harvest \\
\hline 3. & Plant height & 7 & $\begin{array}{l}21,35,49,63,77,91 \\
\text { and at harvest. }\end{array}$ \\
\hline 4. & Number of functional leaves & 7 & $\begin{array}{l}21,35,49,63,77,91 \\
\text { and at harvest. }\end{array}$ \\
\hline 5. & Number of nodules per plant & 7 & $\begin{array}{l}21,35,49,63,77,91 \\
\text { and at harvest. }\end{array}$ \\
\hline 6. & Number of gynophores per plant & 5 & $\begin{array}{l}49,63,77,91 \\
\text { and at harvest. }\end{array}$ \\
\hline 7. & Number of branches per plant & 7 & $\begin{array}{l}21,35,49,63,77,91 \\
\text { and at harvest. }\end{array}$ \\
\hline 8. & Number of pods per plant & 5 & $\begin{array}{l}49,63,77,91 \\
\text { and at harvest. }\end{array}$ \\
\hline 9. & Dry matter production per plant & 7 & $\begin{array}{l}21,35,49,63,77,91 \\
\text { and at harvest. }\end{array}$ \\
\hline II. & \multicolumn{3}{|l|}{ Yield Studies: } \\
\hline 1. & Mean pod weight per plant & 1 & At harvest \\
\hline 2. & Pod yield & 1 & At harvest \\
\hline 3. & Straw yield & 1 & At harvest \\
\hline 4. & Pod: Straw ratio & 1 & At harvest \\
\hline 5. & Harvest index & 1 & At harvest \\
\hline 6. & Test weight & 1 & At harvest \\
\hline III. & \multicolumn{3}{|l|}{ Weed Studies: } \\
\hline 1. & $\begin{array}{l}\text { Weed count, annual grasses, } \\
\text { broad leaved and perennial weeds. }\end{array}$ & 7 & $\begin{array}{l}21,35,49,63,77,91, \\
\text { and at harvest }\end{array}$ \\
\hline 2. & $\begin{array}{l}\text { Weed mortality \% of grasses, } \\
\text { broad leaved and perennial weeds }\end{array}$ & 7 & $\begin{array}{l}21,35,49,63,77,91, \\
\text { and at harvest }\end{array}$ \\
\hline 3. & Dry matter weight of weeds & 1 & At harvest \\
\hline 4. & Weed index & 1 & At harvest \\
\hline 5. & Herbicidal efficiency & 1 & At harvest \\
\hline IV. & \multicolumn{3}{|l|}{ Chemical Studies: } \\
\hline 1. & $\begin{array}{l}\text { Nitrogen uptake by weeds and crop } \\
\text { plants. }\end{array}$ & 1 & At harvest \\
\hline V. & Economics of weed control & 1 & At harvest \\
\hline
\end{tabular}

